\title{
TMS 17 Kiralama İşlemleri Standardından TFRS 16 Kiralamalar Standardına Geçişte BIST Şirketlerine Yönelik Sektörel Etkilerin Karşılaştırmalı Analizia
}

\author{
Burak Özdoğan ${ }^{b, c}$, Uğur Uygund
}

Özet

Uluslararası Muhasebe Standartları Kurulu (IASB) tarafından kiralamalar için finansal raporlamanın geliştirilmesi projesi kapsamında IAS 17 (TMS 17) kiralamalar standardının yerini almak üzere hazırlanan IFRS 16 (TFRS 16), 1 Ocak 2019 itibariyle yürürlüğe girmiştir. Yenilenen standartla birlikte kiracılar açısından finansal kiralama ve faaliyet kiralaması ayrımı ortadan kaldırılarak bilgi kullanıcılarının daha doğru karar alması ve finansal tabloların işletmelerin mevcut durumunu daha gerçeğe uygun yansıtması imkanı sağlanmıştır. Standardın uygulamaya geçişiyle birlikte, özellikle faaliyet kiralaması işlemleri bulunan şirketlerin finansal tablolarında önemli değişikliklerin yaşanması beklenmektedir. Bu çalışmayla, Türkiye'de Borsa İstanbul'da faaliyet gösteren işletmeler sektörel bazda sınıflandırılarak yeni kiralamalar standardından finansal tablolarının etkilenme seviyesi IASB tarafından yayımlanan etki raporunda yer alan sektör ortalamalarıyla karşılaştırılmıştır. Sonuç olarak, en fazla etkilenen sektörlerin perakende, havacılık ve sağlık olduğu tespit edilirken Türkiye'deki sektörel etki seviyelerinin IASB çalışmasıyla zaman zaman farklılık gösterdiği ortaya konmuştur.
Anahtar Kelimeler

TMS 17

TFRS 16

Kiralama Standard 1

Makale Hakkında

Geliş Tarihi: 11.10.2019

Kabul Tarihi: 10.06.2020

Doi: 10.18026/cbayarsos.632089

\section{Comparative Analysis of Sectoral Impacts to BIST Companies in Transition From IAS 17 Leasing Standard to IFRS 16}

\begin{abstract}
IFRS 16 (TFRS 16), prepared by the International Accounting Standards Board (IASB) to replace the IAS 17 (TMS 17) leases standard as part of the project to improve financial reporting for leases, has been effective as of January 1, 2019. With the renewed standard, the distinction between financial leasing and operating leases has been eliminated, allowing information users to make more accurate decisions and allow financial statements to reflect the current situation of the businesses more realistically. With the implementation of the standard, significant changes are expected to occur in the financial statements of companies with operating lease transactions. With this study, the level of impact of financial statements after the new leases are classified on a sectoral basis by the companies operating in Borsa Istanbul in Turkey with the sector averages included in the impact report published by the IASB compared. Consequently, it was found that retail, aviation and health were the most affected sectors, while sectoral impact levels in Turkey differed from time to time with the IASB study.
\end{abstract} Keywords

\begin{tabular}{r} 
Keywords \\
\hline IAS 17 \\
IFRS 16 \\
Leasing Standard \\
\\
About Article \\
\hline Received: 11.10 .2019 \\
Accepted: 10.06 .2020
\end{tabular}

Doi: $10.18026 /$ cbayarsos.632089

\footnotetext{
a Bu çalışma, Uğur Uygun'un 02/08/2019 tarihinde kabul edilen 578361 nolu “Yeni Kiralamalar Standardı TFRS 16'nın İşletmelerin Finansal Durumuna Etkileri: BİST Şirketleri Üzerine Bir Uygulama" başlıklı yüksek lisans tezinden türetilmiştir.

b İletisim Yazarı: burak.ozdogan@cbu.edu.tr

c Dr. Öğr. Üyesi, Manisa Celal Bayar Üniversitesi, İ.̇̇.B.F, Muradiye Kampüsü, ORCID: 0000-0002-8504-5085.

d Bilim Uzmanı, Manisa Celal Bayar Üniversitesi, İ.İ.B.F, Muradiye Kampüsü, ORCID: 0000-0001-6357-3760.
} 


\section{Giriş}

Türkiye'de 31 Aralık 2005 tarihinden sonra başlayan hesap dönemlerinden itibaren uygulamada bulunan Türkiye Muhasebe Standardı 17 (TMS 17), finansal kiralama işlemleri ile ilgili eski muhasebe standardını ifade etmektedir. TMS 17, 31 Aralık 2018 tarihine kadar yürürlükte kalmış olup yerini bu tarihten sonra başlayan hesap dönemlerinde uygulanmak üzere Türkiye Finansal Raporlama Standartları 16 (TFRS 16)'ya bırakmıştır. TFRS 16, finansal kiralama işlemleri konusunda yeni muhasebe standardını ifade etmektedir. Standarttaki değişimle birlikte, işletmelerin finansal tablolarını etkileyecek önemli yenilikler ortaya çıkmıştır. Bu değişimle birlikte işletmelerin finansal durum tabloları, kar veya zarar tabloları ve nakit akış tablolarında işletme paydaşlarının kararlarını etkileyebilecek güncellemeler meydana gelmiştir.

$\mathrm{Bu}$ çalışma ile, kiralama işlemlerine yönelik standartta meydana gelen değişimlerin bu işlemlere konu faaliyetlerde bulunan şirketlere yönelik etkilerini ortaya koymak amaçlanmaktadır. Çalışmada öncelikle TMS 17 ve TFRS 16 standartları arasındaki farklılıklar kapsamlı biçimde ele alınmıştır. Devam eden bölümde, öncelikle bir literatür taraması gerçekleştirilerek bu konuyu odağına alan çalışmalar incelenmiştir. Sonrasında ise Türkiye' de Borsa İstanbul' da (BİST) yer alan işletmeleri bu değişimin nasıl etkilediğini ortaya koyabilmek ve dünya genelinde beklenen değişimle bir fark olup olmadığını tespit edebilmek amacıyla IASB tarafından yayımlanan etki raporu sonuçları ile BIST şirketlerinin ilgili kalemlerine yönelik sonuçlar karşılaştırılmıştır. Çalışma, bulguların değerlendirilmesi ile tamamlanmıştır.

\section{TMS 17 ile TFRS 16 Standartlarındaki Farklılıkların Karşılaştırması}

TMS 17 ve TFRS 16 standartları arasındaki en temel farklılık, kiracı açısından finansal ve faaliyet kiralaması ayrımının kaldırılması ve tüm işlemlerin bir finansal kiralama olarak değerlendirilmesidir. TFRS 16 ile birlikte, daha önce finansal durum tablosu dişında tutulan faaliyet kiralaması işlemleri, finansal durum tablosu içerisine alınmıştır (Öztürk, 2016: 20). Standartlar arasındaki karşılaştırmayı; ilk muhasebe işlemleri açısından, sonraki dönem muhasebe işlemleri açısından, finansal tabloların sunumu ve dipnotlar yönünden dört ana başlığa ayırarak incelemek mümkündür.

\section{Standartlar Arasındaki Farklılıkların İk Muhasebeleştirme İşlemlerinin Karşılaştırılması}

TMS 17 ve TFRS 16, ilk muhasebeleştirme işlemleri bakımından ele alındığında dikkat çeken birincil farklılık, kiracının artık özün önceliğini dikkate alarak değerlendirme yapma zorunluluğunun ortadan kaldırılarak tüm kiralama işlemlerinin finansal kiralama işlemiymiş gibi kabul edilmesi olarak görülmektedir (Öztürk, 2016: 13). Bu değişimin temel amacını, IASB (2016a: 12), kiracı açısından tüm kiralama işlemlerini finansal tablo içerisine alabilmek şeklinde açıklamaktadır. Diğer taraftan, yine daha önce finansal durum tablosuna yansıtılacak tutarın belirlenmesi için karşılaştırma yapma zorunluluğu da kiracı açısından ortadan kaldırılmış ve bugünkü değer üzerinden muhasebeleştirme getirilmiştir (TFRS 16/m.26).

Yine iki standart arasındaki bir diğer farklılık olarak, kira ödemelerinin bugünkü değerinin hesaplamasında kullanılacak faiz oranının belirlenmesinde ortaya çıkmaktadır. TFRS 16, faiz oranı tespitinde kiracıya TMS 17 ile tanınan seçimlik hakkına son vererek borçlanma faiz oranının "kiracının benzer bir ekonomik ortamda kullanma hakkı varlığıyla benzer değerde 
bir varlık elde etmek için gerekli olan fonları, benzer bir dönem ve benzer güvence ile borç alması halinde ödemek zorunda olduğu faiz oranı" olarak alınmasını düzenlemiştir (TFRS 16/ Ek A).

\section{Standartlar Arasındaki Farklılıkların Sonraki Dönem Muhasebeleştirme İşlemlerinin Karşılaştırılması}

TMS 17 ile TFRS 16 arasında, kiracı tarafından sonraki dönemlerde yapılacak muhasebe işlemleri bakımından da bazı farklılıklar bulunmaktadır. TMS 17'de kiracının kullanım hakkını elde tuttuğu varlığı sonraki dönemlerde hangi yönteme göre takip edeceğine dair bir netlik bulunmamaktadır. Ancak TFRS $16^{\prime}$ da bu konu açık bir hükme bağlanmış ve kiracının kullanım hakkını elde tuttuğu varlığı ilk muhasebeleştirmeden sonra aksi belirtilmediği sürece maliyet modeline göre izleyeceği ifade edilmiştir (TFRS 16/m.29).

TMS 17'de olmayan bir muhasebe politikası seçeneği olarak yeniden değerleme modeli, kiracının sonraki dönem muhasebeleştirmelerinde uygulayabileceği bir yöntem olarak TFRS 16 'da bir seçenek olarak belirtilmiştir (TFRS 16/m.29). Diğer taraftan amortisman süresi bakımından değerlendirildiğinde, kiralamaya konu varlığın kiracı tarafından satın alınması durumu ile ilgili TMS 17 sadece sözleşmeye konu varlığın kiracı tarafından satın alınacağının kesine yakın olması ihtimalini kabul etmiş iken (TMS 17/m.28), TFRS 16 hem varlığını kiralama süresi sonunda kiracıya devredilmesi yani satılması hem de kullanım hakkı varlığının maliyetinin kiracının satın alma opsiyonunu kullanacağını göstermesi durumları (TFRS 16/m.32) kabul edilmiştir. Bir diğer dikkat çeken değişiklik olarak, TFRS 16' da kiralama işlemlerinden doğan borçlar hesabının daha ayrıntılı düzenlendiği ve daha geniş açıklamalara yer verildiği görülmektedir.

\section{Standartlar Arasındaki Farklılklarn Finansal Tabloların Sunumu Yönünden Karşılaştırılması}

Her iki standart da incelendiğinde, finansal kiralama işlemlerinin finansal tablolara alınmasına yönelik düzenlemeler görülmekle birlikte, bu düzenlemelerin TFRS 16 kapsamında daha ayrıntılı şekilde ele alındığı anlaşılmaktadır. TMS 17 kapsamında, 20. maddede açıklandığı üzere, sadece finansal kiralama işlemlerinin finansal durum tablosunda varlık ve borç olarak muhasebeleştirmesi istenirken TFRS 16 bu ayrımı ortadan kaldırarak kiralama işlemlerinin finansal durum tablosunda muhasebeleştirilmesini kullanım hakkı elde tutulan varlık ve kiralama işleminden borçlar bağlamında ayrıntılı bir şekilde ele almıştır. Buna göre;

- "Finansal durum tablosunda kullanım hakkı elde tutulan varlıklar, diğer varlıklardan ayrı olarak gösterilir. Varlıkların bu şekilde ayrı olarak raporlanamaması durumunda, dipnotlarda hangi bilanço kalemi içinde kullanım hakkı elde tutulan varlık olduğu açılanır" (TFRS 16/m.47a).

- “Finansal durum tablosunda kiralama işleminden kaynaklanan yükümlülükler, diğer yükümlülüklerden ayrı olarak gösterilir. Yükümlülüklerin ayrı bir şekilde gösteriminin mümkün olmaması halinde dipnotlarda bu yükümlülüklerin hangi borç kalemi içinde olduğu açıklanır" (TFRS 16/m.47b). 
TFRS 16'nın, TMS 17'den ayrıldığı en önemli noktalardan biri de daha önce finansal durum tablosu dışında bırakılan bir kısım kiralama işlemlerinin bilanço içine taşınmış olmasıdır. Bu değişiklik, bu zamana kadar TMS 17 kapsamında ilgili varlık ve yükümlülüklerinin finansal durum tablosu dışında bırakan işletmelerin tablolarında önemli değişikliklere sebep olabilecektir. TFRS 16 bir yandan tüm kiralama işlemlerini bilanço içine taşırken bir yandan da süre ve miktar olarak önemsiz olan sözleşmeleri kapsam dışına çıkartarak kiracının iş yükünde bir azalmayı hedeflemektedir (Parlak, 2018: 87). Buna göre, kiralama süresi 1 yıl ve altı olan sözleşmeler ile miktar olarak düşük tutarlı kiralama sözleşmelerinin varlık ve yükümlülük olarak muhasebeleştirilmemesi konusunda kiracıya seçimlik hak tanımaktadır.

TMS 17'ye göre sadece finansal kiralama işlemlerini finansal durum tablosunda gösterdiği için, sadece finansal kiralama işlemleri ile ilgili faiz giderleri bir finansman gideri olarak kar veya zarar tablosunda kendine yer bulmakta ve yine bu işlemler ile ilgili olarak amortisman gideri ayrılmaktaydı. Faaliyet kiralaması ile ilgili giderler ise doğrudan faaliyet giderleri olarak kaydedilmekteydi. TFRS $16^{\prime}$ da ise, kiracı bakımından istisnalar dışında kalan tüm kiralama işlemleri bir finansal kiralama işlemi olarak kabul edilmiştir. Buna bağlı olarak tüm kiralama işlemleri için amortisman ayrılacak ve kira ödemeleri esnasında ortaya çıkan faiz ödemeleri de bir finansman gideri olarak dikkate alınacaktır. Bu bağlamda TFRS 16'nın uygulanması ile Kâr veya Zarar ve Diğer Kapsamlı Gelir Tablosu'nun sürdürülen faaliyetlere ilişkin dönem kâr/zararı kısmında önemli değişiklikler olması beklenmektedir (Öztürk, 2016: 29). Nakit akış tablosuna etkiler bakımından değerlendirildiğinde ise, TMS 17 'de finansal kiralama işlemlerinin nakit akış tablosunda nasıl yer alacağına dair bir düzenlemeye yer verilmemiş ancak TFRS 16'da bu konu ayrıntılı bir şekilde ele alınmıştır (TFRS 16, m.50). Buna göre;

- Kira ödemelerinin anapara kısmına ilişkin nakit ödemeleri Nakit Akış Tablosu'nun finansman faaliyetlerinde,

- Kira ödemelerinin faiz kısmına ilişkin nakit ödemeleri tablonun ödenen faizlere ilişkin hükümleri çerçevesinde ve

- İstisna tutulan kiralamalara (12 aydan kısa süreli, düşük değerli) ilişkin ödemeler ile değişken kira ödemeleri işletme faaliyetlerinde raporlanacağ $\breve{1}_{1}$ fade edilmiştir (TFRS 16, m.50).

\section{Standartlar Arasındaki Farklılıkların Dipnotlar Yönünden Karşılaştırılması}

TFRS 16'da dipnotlar konusu TMS 17'ye nazaran daha kapsamlı şekilde ele alınmıştır. TFRS 16 standardı ile dipnotların şeffaflı̆̆ 1 arttırılarak finansal durum tablosu, kar veya zarar tablosu ve nakit akış tablosu ile bağlantılı olarak kiracının dipnot bilgilendirmelerine yönelik standartlar oluşturulmuştur. TFRS 16 kapsamında madde 51 ve 60 arasında, dipnotlarda istenen açıklamalar sıralanmıştır. Bunlar arasında; her bir varlık için dönemde yapılan ilaveler, kullanım hakkı elde tutulan her varlığın dönem sonundaki defter değeri, her bir varlık için dönem amortisman gideri ve kiralama işlemlerinden kaynaklanan nakit çıkışları toplamı gibi maddeler yer almaktadır (TFRS 16 / m.51-60). 


\section{Yöntem}

Çalışmanın bu bölümünde, TMS 17 ve TFRS 16'nın sektörler üzerindeki genel etkisinin karşılaştırmalı olarak incelenmesi amacılya öncelikle literatür taraması gerçekleştirilmiş ve kiralama işlemlerine ilişkin standart değişikliğini ve etkilerini odağına alan çalışmalara yer verilmiştir. Sonrasında ise, IASB tarafından 2016 yılında yayımlanan Etki Analizi Raporu'nda, yeni düzenlemenin hangi sektörler üzerinde daha fazla etki edeceği inceleme konusu yapılarak ilgili sektörler ve etkilenme seviyeleri belirtilmiştir. IASB raporunda yer alan sektörlerin BIST'deki karşılıkları tespit edilerek 7 sektör seçilmiş ve seçilen 7 sektörde yer alan şirketler arasından en az 1 şirketin finansal tablolarındaki değişimler araştırma konusu yapilmiştır.

\section{Kiralama Standardındaki Değişime İlişkin Literatür Taraması}

Kiralama işlemlerine yönelik standardın değişimi araştırmacılar tarafından hem uluslararası hem de ulusal literatürde inceleme konusu edilen önemli bir alan olmuştur. Bu kapsamdaki kimi çalışmalar standart henüz taslak halindeyken gerçekleştirilmiş kimi ise yayımlanmasından ve uygulamaya geçirilmesinden sonra hazırlanmıştır.

Beattie vd. (2006) bütün kiralama işlemlerinin bilançoda gösterilmesi gereğine ilişkin tartışmalara yer verdiği çalışmada, birçok işletme için faaliyet kiralaması yoluyla finansman sağlamanın finansal kiralamaya göre çok daha önemli boyutlara ulaştığını vurgulamaktadırlar. İngiltere' de finansal tablo kullanıcısı ve hazırlayıcısı 132 kişinin katıldı $\breve{g}$ anket çalışmalarında iki grup anket katılımcısı da mevcut standardın çeşitli açlardan yetersiz kaldığını belirtmiştir ancak raporları hazırlayanların kiralamalarla ilgili düzenlemelerin kullanıcıların kararını farklılaştıracağına inanmadıklarını ortaya koymuştur (Beattie vd., 2006).

Gritta ve Lippman (2010) Amerikan havayolu şirketlerinin 1960'lardan itibaren uçaklarını büyük ölçüde finansal kiralama yoluyla edindiklerini, 1976 yılında FASB (Financial Accounting Standards Board) tarafından yayınlanan SFAS No. 13 ile finansal kiralamaların bilançoda varlık ve yükümlülük olarak raporlanması gerekliliğine ilişkin düzenlemeden sonra ise uçaklarının finansmanını kısa dönemli faaliyet kiralaması şeklinde sağlama yolunu tercih ettiklerini belirtmektedirler. Çalışmalarında 2008 yılında havayolu şirketlerinin kiralama kullanımlarını ve 1974 ve 1995 'te gerçekleştirdikleri çalışmalara göre değişimi belirlenmiş ve bazı şirketlerin filolarının tamamını faaliyet kiralaması yoluyla finanse ettiğini ortaya koymuşlardır.

Ulaşım sektörünü konu alarak benzer bir çalışma gerçekleştiren Tang ve Fiedler (2011) bu sektörde kullanılan taşıtlarda ağırlıklı olarak faaliyet kiralamasının tercih edildiği kanaatiyle sektör temsilcilerinin aslında borçlarını finansal durum tablosuna taşımayarak gizlediğini ve etik dışı davrandığını iddia etmektedir. Özellikle havayolu işletmelerinde faaliyet kiralaması ödemelerinin finansal kiralama ödemelerine oranının 26/1 olarak tespit edildiği çalışmada, yöneticilerin kiralama işlemlerini "faaliyet kiralaması" olarak sınıflandırarak performanslarını yüksek gösterme ve dolayısıyla kendi çıkarlarına hizmet etme eğiliminde olabilecekleri, mevcut standardın da yasal ancak etik olmayan bu manevraya imkân sağladığ vurgulanmaktadır. 
Hava yolu sektörüne yönelik etkileri anlamak üzere Şenyiğit (2014) yaptığg vak'a çalışmasında büyük ölçekli bir ulaşım sektörü temsilcisi olan Delta Havayolları'nın 2010 yılına ait faaliyet raporunu incelemiştir. Delta Havayolları'nın uçaklarının büyük ölçüde faaliyet kiralaması ile finanse edildiğini ve faaliyet kiralaması ödemelerinin finansal kiralama ödemelerinin çok üstünde olduğunu belirtmekte ve UFRS 16'nın uygulanmasıyla birlikte işletmenin performansını gösteren birçok oranda azalma olacağını ve bununla birlikte borçlanma oranlarının artacağını savunmaktadır.

Aktaş, Karğın ve Demirel Arıcı (2017) TFRS 16 ile TMS 17arasındaki karşılaştırma eksenli çalışmalarında önce hipotetik bir işletme üzerinden konuyu ele almışlardır. Yazarlar, teknoloji perakende şirketi BİMEKS ile ulaşım sektöründen Pegasus'a ait finansal tablolardaki olası değişimi hesaplamış ve Şenyiğit (2014)'i doğrular şekilde borçlanma oranlarındaki artış1 ortaya koymuşlardır.

Kaval (2018), çalışmasında Türkiye'de standardın yürürlüğe girişiyle birlikte ortaya çıkacak geçiş süreci ve finansal tablolar üzerindeki olası etkileri tartışmıştır. Marşap ve Yanık (2018), çalışmalarında TFRS 16'nın finansal raporlama süreçlerine etkisini konu edinmiş ve standardın getirdiklerini kapsamlı bir çerçevede ele alarak yorumlamıştır. Yazarlar, bir başka çalışmalarında ise standardı BOBİ FRS ile karşılaştırmış ve TMS 17 ile BOBİ FRS 15. Bölümünün tam olarak örtüşmekte iken henüz TFRS 16 ile bu uyumun oluşmadığ belirtilmiştir (Marşap ve Yanık, 2019). Hazır (2018), çalışmasında kiralama işlemlerinin yeni standarda göre muhasebeleştirilmesi sürecini ayrıntılı biçimde açılamıştır. Hazır (2019), bir diğer çalışmasında ise konuyu grup içi muhasebe politikaları açısından ele almış ve sonuç olarak özellikle yatırımcı ilişkileri bakımından muhasebe politikalarındaki standartla uyumlu değişikliklerin olumlu sonuçlar doğuracağını savunmuştur.

Sarı ve Güngör (2019), çalışmalarında BİST 100'de yer alan 63 şirketin finansal tablolarını incelemiş ve dönem karı, faaliyet karı, toplam varlıklar ve yükümlülükler kalemlerinde yukarı ve aşağ 1 yönlü değişimler gerçekleştiğini tespit etmişlerdir. Akdoğan (2019) çalışmasında BİST perakende sektöründe faaliyet gösteren şirketleri incelemiştir. Çalışma sonuçlarına göre, TFRS 16'nın uygulanması ile işletmelerin kısa ve uzun vadeli yabancı yükümlülükleri artmıs, aynı şekilde kullanım hakkı varlıklarının faaliyet kiralamalarını da kapsaması nedeniyle aktifte duran varlık toplamları artmıştır. Bunun sonucunda işletmelerin aktif ve pasif toplamlarında artış olmuştur.

\section{IASB Etki Analizi Raporu Sektörel Etki Sonuçları ile BIST Sektörel Etkilerinin Belirlenen Şirketler Kapsamında Karşılaştırılması}

TMS 17 ile TFRS 16 arasında kiracılar bakımından en önemli farklılık, TMS 17 uygulamalarında bilanço dışı bırakılan faaliyet kiralaması işlemlerinin TFRS 16 ile istisnalar dışında bütünüyle bilanço içine alınmasıdır. TFRS 16' nın hazırlanma sürecinde, bu standardın sektörler üzerindeki etkisinin ne olacağ ile ilgili olarak IASB çok sayıda araştırma yapmış ve bunları kamuoyu ile paylaşmıştır. Bu çalışmalardan bir tanesi, 1022 şirketi kapsayan "Etki Analizi Raporu" olup elde edilen sonuçlar aşağıdaki gibi özetlenmiştir: 
Tablo 1: Sektör Bazında Bilanço Dışı Ödemelerin Toplam Varlıklara Oranı

\begin{tabular}{|c|c|c|c|c|}
\hline Endüstri/Sektör & $\begin{array}{l}\text { Toplam } \\
\text { Şirket } \\
\text { Sayısı }\end{array}$ & $\begin{array}{l}\text { Toplam } \\
\text { Varlıklar } \\
\text { (Milyon ABD } \\
\text { Doları) }\end{array}$ & $\begin{array}{l}\text { Bilanço Dişı } \\
\text { Birakılan } \\
\text { Gelecekteki } \\
\text { Ödemeler (Milyon } \\
\text { ABD Doları) }\end{array}$ & $\begin{array}{l}\text { Bilanço Dışı } \\
\text { Bırakılan } \\
\text { Gelecekteki } \\
\text { Ödemeler/ } \\
\text { Toplam Varlıklar }\end{array}$ \\
\hline Havayolu & 50 & 526.763 & 151.549 & $28,8 \%$ \\
\hline Perakende & 204 & 2.019 .958 & 571.812 & $28,3 \%$ \\
\hline Seyahat & 69 & 403.524 & 115.300 & $28,6 \%$ \\
\hline Taşımacılık & 51 & 585.964 & 90.598 & $15,5 \%$ \\
\hline Telekomünikasyon & 56 & 2.847 .063 & 219.178 & $7,7 \%$ \\
\hline Enerji & 99 & 5.192 .938 & 400.198 & $7,7 \%$ \\
\hline Medya & 48 & 1.020 .317 & 71.743 & $7,0 \%$ \\
\hline Dağıtım & 26 & 581.503 & 31.410 & $5,4 \%$ \\
\hline Bilgi Teknolojileri & 58 & 1.911 .316 & 69.870 & $3,7 \%$ \\
\hline Sağlık & 55 & 1.894 .933 & 72.149 & $3,8 \%$ \\
\hline Diğer & 306 & 13.959 .223 & 401.703 & $2,9 \%$ \\
\hline Toplam & 1.022 & 30.943 .502 & 2.195 .510 & $7,1 \%$ \\
\hline
\end{tabular}

Kaynak: IASB, 2016: 16

IASB çalışmasında görüldüğü üzere, yeni standart ile en çok etkilenecek sektörlerin başında oransal olarak havayolu sektörü, tutar olarak ise perakende sektörü gelmektedir. Bu durum incelendiğinde havayolu sektöründe özellikle uçak ve uçak motoru kiralamalarının; perakende sektöründe ise özellikle mağaza kiralamalarının, eski standart kapsamında birer faaliyet kiralaması olarak nitelendirilmesi nedeniyle bilanço dışında bırakılmasının etkili olduğu görülmektedir. IASB çalışmasının yol göstericiliğinde, TFRS 16'nın Türkiye'deki halka açık şirketler üzerindeki etkisi araştırılmıştır. Bu bağlamda öncelikle IASB raporunda yer alan sektörlerden BİST'te de yer alanlar seçilerek ilgili sektörlerde yer alan BİST şirketleri tespit edilerek Tablo 2'deki gibi sınıflandırılmıştır.

Tablo 2: IASB Raporuyla Uyumlu Olarak BIST Sektörleri ve Şirketler

\begin{tabular}{|c|c|c|}
\hline $\begin{array}{l}\text { Endüstri/Sektör } \\
\text { (UMSK) }\end{array}$ & $\begin{array}{l}\text { Sirket } \\
\text { Sayısı }\end{array}$ & Şirketler \\
\hline \multirow{4}{*}{ Havayolu-TaşımacılıkUlaştırma } & \multirow{4}{*}{8} & 1- Beyaz Filo Oto Kiralama A.Ş. \\
\hline & & 2- Çelebi Hava Servisi A.Ş. \\
\hline & & 3- Do \& Co Aktiengesellschaft \\
\hline & & 4- Gsd Denizcilik Gayrimenkul İnşaat San.Tic.A.Ș. \\
\hline
\end{tabular}




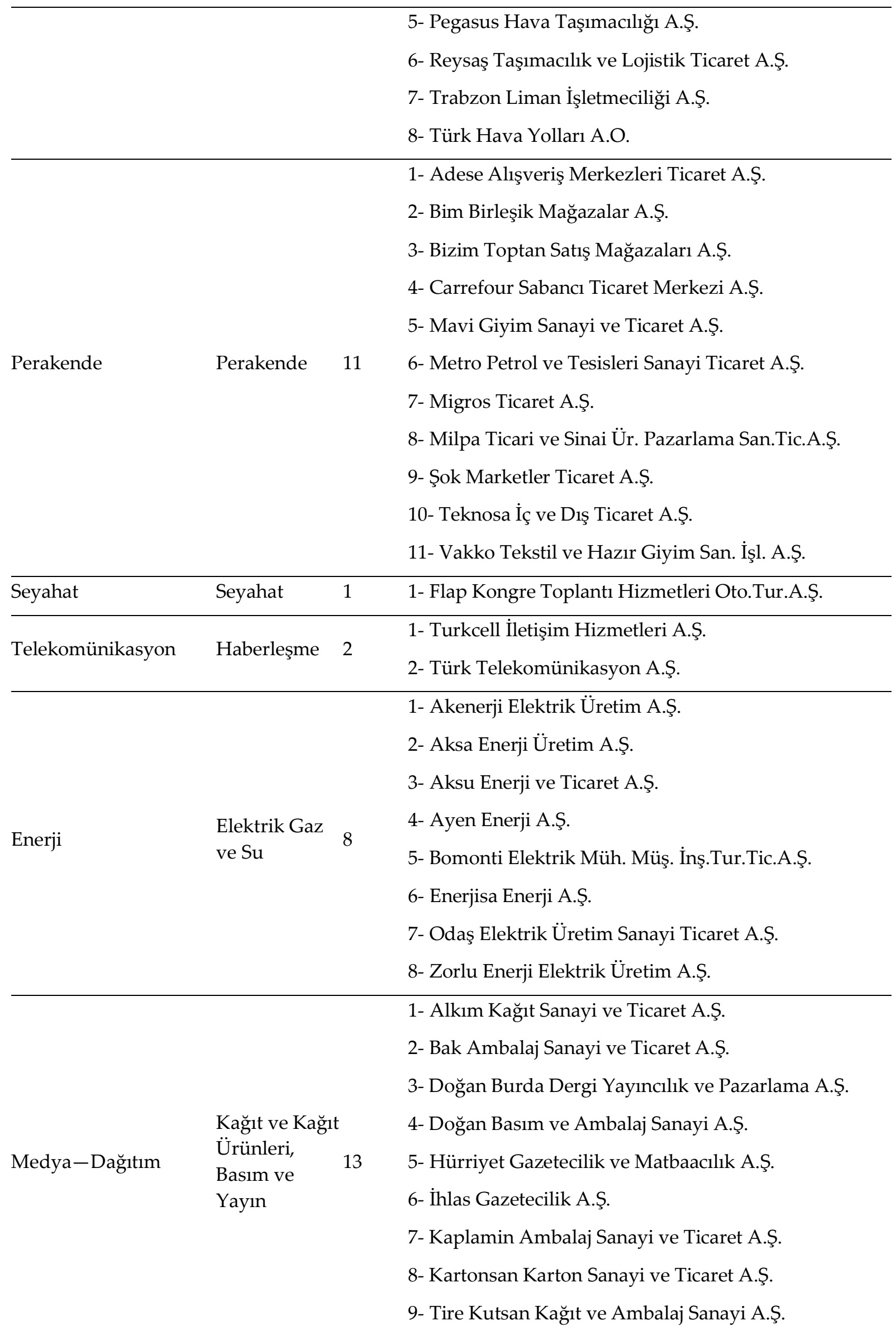




\begin{tabular}{|c|c|c|}
\hline & & $\begin{array}{l}\text { 10- Olmuksan Int. Paper Amb. San. Tic. A.Ş. } \\
\text { 11- Prizma Pres Matbaacılık Yay. San. Tic. A.Ş. } \\
\text { 12- Saray Matbaacilik Kağ. Kırt. Tic. San. A.Ş. } \\
\text { 13- Viking Kağıt ve Selüloz A.Ş. }\end{array}$ \\
\hline Bilgi Teknolojileri & $\begin{array}{l}\text { Teknoloji- } \\
\text { Bilişim }\end{array}$ & $\begin{array}{l}\text { 1- Alcatel Lucent Teletaş Telekomünikasyon A.Ş. } \\
\text { 2- Arena Bilgisayar Sanayi ve Ticaret A.Ş. } \\
\text { 3- Armada Bilgisayar Sistemleri San. ve Ticaret A.Ş. } \\
\text { 4- Datagate Bilgisayar Malzemeleri Ticaret A.Ş. } \\
\text { 5- Despec Bilgisayar Pazarlama ve Ticaret A.Ş. } \\
\text { 6- Escort Teknoloji Yatırım A.Ş. } \\
\text { 7- Fonet Bilgi Teknolojileri A.Ş. } \\
\text { 8- İndeks Bilgisayar Sistemleri Müh. San.Tic. A.Ş. } \\
\text { 9- Kafein Yazılım Hizmetleri Ticaret A.Ş. } \\
\text { 10- Karel Elektronik Sanayi ve Ticaret A.Ş. } \\
\text { 11- Kron Telekomünikasyon Hizmetleri A.Ş. } \\
\text { 12- Link Bilgisayar Sist. Yaz. Don. San. Tic. A.Ş. } \\
\text { 13- Logo Yazılım Sanayi ve Ticaret A.Ş. } \\
\text { 14- Netaş Telekomünikasyon A.Ş. } \\
\text { 15- Plastikkart Akıllı Kart İletişim Sis. San. Tic. A.Ş. } \\
\text { 16- Smartiks Yazılım A.Ş. }\end{array}$ \\
\hline Sağlık & $\begin{array}{l}\text { Eğitim, Sağlık, } 6 \\
\text { Spor }\end{array}$ & $\begin{array}{l}\text { 1- Beşiktaş Futbol Yatırımları San.Tic. A.Ş. } \\
\text { 2- Fenerbahçe Futbol A.Ş. } \\
\text { 3- Galatasaray Sportif Sınai ve Ticari Yat. A.Ş. } \\
\text { 4- Lokman Hekim Engürüsağ Sağ. Tur. Eği. A.Ş. } \\
\text { 5- Mlp Sağlık Hizmetleri A.Ş. } \\
\text { 6- Trabzonspor Sportif Yat. Fut. İşl. Tic. A.Ş. }\end{array}$ \\
\hline Diğer* & İmalat & $\begin{array}{l}\text { 1- Deva Holding A.Ş. } \\
\text { 2- Borusan Mannesmann Boru San. ve Ticaret A.Ş. } \\
\text { 3- Coca-Cola İçecek A.Ş. } \\
\text { 4- Dyo Boya Fabrikalari Sanayi ve Ticaret A.Ş. } \\
\text { 5- Ford Otomotiv Sanayi A.Ş. } \\
\text { 6- Otokar Otomotiv ve Savunma Sanayi A.Ş. } \\
\text { 7- Tüpraş-Türkiye Petrol Rafinerileri A.Ş. }\end{array}$ \\
\hline
\end{tabular}

Tablo 2'de görüleceği üzere, IASB çalışmasındaki sektörler bazında BİST'te işlem gören toplam 72 tane şirket bulunmaktadır. Sınıflandırmaya dahil edilen bu şirketlerin 2018 yılı 
finansal raporlarına erişim sağlanarak hangilerinin kiralama (finansal veya faaliyet) işlemi yaptıkları araştırılmıştır. 2018 yılının seçilmesinin nedeni, TFRS 16'nın 31.12.2018 tarihinden sonra başlayacak olan hesap dönemleri için uygulamaya girecek olmasıdır. Sınıflandırmaya dahil edilen 72 şirketin finansal tabloları incelenerek 2018 yılı itibariyle finansal ve/veya faaliyet kiralaması işlemlerine yönelik bilgiler elde edilmiştir. Ortaya çıkan yapı Ek 1'de sunulmuştur. Elde edilen veriler 1şığında; perakende sektöründe, kiralama işleminin yoğun bir şekilde kullanıldığı, faaliyet kiralamasının ise finansal kiralamaya kıyasla daha fazla tercih edildiği görülmektedir.

Tablo 3: Seçilmiş Sektörlerdeki BİST Şirketlerinin Bilanço Dışı Ödemelerinin Toplam Varlıklarına Oranı

\begin{tabular}{|c|c|c|c|c|}
\hline $\begin{array}{l}\text { SEKTÖR } \\
\text { (BİST) }\end{array}$ & ŞİRKET & $\begin{array}{l}\text { Toplam } \\
\text { Varliklar } \\
\text { (TL) }\end{array}$ & $\begin{array}{l}\text { Bilanço Dışı } \\
\text { Bırakılan } \\
\text { Gelecekteki } \\
\text { Ödemeler } \\
\text { (TL) }\end{array}$ & $\begin{array}{l}\text { Bilanço Dişı } \\
\text { Birakılan } \\
\text { Gelecekteki } \\
\text { Ödemeler/ } \\
\text { Top. Var. }\end{array}$ \\
\hline \multirow{8}{*}{ Ulaştırma } & 1- Beyaz Filo Oto Kiralama A.Ş. & 171.084 .387 & - & $0,00 \%$ \\
\hline & 2- Çelebi Hava Servisi A.Ş. & 1.522.060.041 & 145.337 .603 & $9,55 \%$ \\
\hline & 3- Do \& Co Aktiengesellschaft & 0 & - & $0,00 \%$ \\
\hline & 4- Gsd Deniz. Gayr. İnş. San.Tic.A.Ş. & 296.999 .000 & - & $0,00 \%$ \\
\hline & 5- Pegasus Hava Taşımacılığı A.Ş. & 13.664.887.536 & 3.680 .574 .546 & $26,93 \%$ \\
\hline & 6- Reysaş Taşımacılık ve Loj. Tic.A.Ş. & 1.377.061.871 & 26.990 .176 & $1,96 \%$ \\
\hline & 7- Trabzon Liman İşletmeciliği A.Ş. & 122.670 .442 & - & $0,00 \%$ \\
\hline & 8- Türk Hava Yolları A.O. & 109.076.000.000 & 11.064 .000 .000 & $10,14 \%$ \\
\hline \multicolumn{2}{|c|}{ Toplam Ulaştırma } & 126.230.763.277 & 14.916.902.325 & $11,82 \%$ \\
\hline \multirow{11}{*}{ Perakende } & 1- Adese Alışveriş Merk. Tic. A.Ş. & 1.218 .534 .883 & - & $0,00 \%$ \\
\hline & 2- Bim Birleşik Mağazalar A.Ş. & 8.947.950.000 & - & $0,00 \%$ \\
\hline & 3- Bizim Toptan Satış Mă̆. A.Ş. & 842.182 .879 & 14.148 .350 & $1,68 \%$ \\
\hline & 4- Carrefour Sabancı Tic. Mer. A.Ş. & 2.648.882.517 & 2.028 .670 .473 & $76,59 \%$ \\
\hline & 5- Mavi Giyim San. ve Ticaret A.Ş. & 1.343.910.000 & 1.556.267.000 & $115,80 \%$ \\
\hline & 6- Metro Petrol ve Tes. San. Tic. A.Ş. & 368.203 .979 & - & $0,00 \%$ \\
\hline & 7- Migros Ticaret A.Ş. & 10.884.861.000 & - & $0,00 \%$ \\
\hline & 8- Milpa Ticari Ür. Paz. San.Tic.A.Ş. & 187.371.244 & - & $0,00 \%$ \\
\hline & 9- Şok Marketler Ticaret A.Ş. & 3.261 .931 .527 & 90.477 .410 & $2,77 \%$ \\
\hline & 10- Teknosa İç ve Diş Ticaret A.Ş. & 760.425 .000 & 841.392 .000 & $110,65 \%$ \\
\hline & 11- Vakko Tekstil ve Haz. San. A.Ş. & 784.164 .165 & 854.607 .361 & $108,98 \%$ \\
\hline \multicolumn{2}{|c|}{ Toplam Perakende } & 31.248.417.194 & 5.385.562.594 & $17,23 \%$ \\
\hline
\end{tabular}




\begin{tabular}{|c|c|c|c|c|}
\hline \multicolumn{2}{|c|}{ Toplam Seyahat } & \multirow{2}{*}{$\begin{array}{l}\mathbf{9 3 . 9 4 8 . 8 6 3} \\
42.765 .275 .000\end{array}$} & \multirow[b]{2}{*}{-} & \multirow{2}{*}{$\begin{array}{l}\mathbf{0 , 0 0 \%} \\
0,00 \%\end{array}$} \\
\hline Holorlocm & 1- Turkcell İletişim Hizmetleri A.Ş. & & & \\
\hline Налескй & 2- Türk Telekomünikasyon A.Ş. & 36.198 .511 .000 & 1.508.740.000 & $4,17 \%$ \\
\hline \multicolumn{2}{|c|}{ Toplam Haberleşme } & 78.963 .786 .000 & 1.508.740.000 & $1,91 \%$ \\
\hline \multirow{8}{*}{$\begin{array}{l}\text { Elektrik Gaz } \\
\text { Ve Su }\end{array}$} & 1- Akenerji Elektrik Üretim A.Ş. & 5.704 .568 .702 & - & $0,00 \%$ \\
\hline & 2- Aksa Enerji Üretim A.Ş. & 6.438 .141 .992 & - & $0,00 \%$ \\
\hline & 3- Aksu Enerji ve Ticaret A.Ş. & 62.541 .020 & - & $0,00 \%$ \\
\hline & 4- Ayen Enerji A.Ş. & 2.668.036.731 & - & $0,00 \%$ \\
\hline & 5- Bomonti Elekt. Müh. İnş. A.Ş. & 48.926 .190 & - & $0,00 \%$ \\
\hline & 6- Enerjisa Enerji A.Ş. & 23.125.041.000 & - & $0,00 \%$ \\
\hline & 7- Odaş Elektrik Ür. San. Tic. A.Ş. & 3.076.063.154 & - & $0,00 \%$ \\
\hline & 8- Zorlu Enerji Elektrik Üretim A.Ş. & 17.163.860.000 & 41.424 .000 & $0,24 \%$ \\
\hline \multicolumn{2}{|c|}{ Toplam Elektrik Gaz ve Su } & 58.287.178.789 & 41.424.000 & $0,07 \%$ \\
\hline \multirow{13}{*}{$\begin{array}{l}\text { Kağıt ve Kağıt } \\
\text { Ürünleri, } \\
\text { Basım ve } \\
\text { Yayın }\end{array}$} & 1- Alkım Kağıt San. ve Ticaret A.Ş. & 220.221 .418 & - & $0,00 \%$ \\
\hline & 2- Bak Ambalaj San. ve Ticaret A.Ş. & 474.593 .852 & - & $0,00 \%$ \\
\hline & 3- Doğan Burda Dergi Yay. Paz. A.Ş. & 52.090 .046 & - & $0,00 \%$ \\
\hline & 4- Doğan Basım ve Amb. San. A.Ş. & 233.197 .868 & 2.879 .988 & $1,23 \%$ \\
\hline & 5- Hürriyet Gazetecilik ve Matb. A.Ş. & 874.168 .650 & - & $0,00 \%$ \\
\hline & 6- İhlas Gazetecilik A.Ş. & 309.404 .740 & - & $0,00 \%$ \\
\hline & 7- Kaplamin Amb. San. ve Tic. A.Ş. & 158.503 .654 & 886.895 & $0,56 \%$ \\
\hline & 8- Kartonsan Karton San. ve Tic. A.Ş. & 269.609 .661 & - & $0,00 \%$ \\
\hline & 9- Tire Kutsan Kağıt Amb. San A.Ş. & 886.443 .444 & - & $0,00 \%$ \\
\hline & $\begin{array}{l}\text { 10- Olmuksan Int. Paper Amb. San. } \\
\text { Tic. A.Ş. }\end{array}$ & 985.429 .939 & - & $0,00 \%$ \\
\hline & 11- Prizma Pres Matb. San. Tic. A.Ş. & 47.383 .639 & - & $0,00 \%$ \\
\hline & 12- Saray Matbaacılık Tic. San. A.Ş. & 105.492 .676 & - & $0,00 \%$ \\
\hline & 13- Viking Kağıt ve Selüloz A.Ş. & 267.114 .393 & - & $0,00 \%$ \\
\hline \multicolumn{2}{|c|}{ Toplam Kağıt ve Kağıt Ürünleri, Basım ve Yayın } & 4.883.653.980 & 3.766 .883 & $0,08 \%$ \\
\hline \multirow{7}{*}{$\begin{array}{l}\text { Teknoloji- } \\
\text { Bilişim }\end{array}$} & 1- Alcatel Lucent Teletaş Tel. A.Ş. & 651.646 .952 & - & $0,00 \%$ \\
\hline & 2- Arena Bilgisayar San. ve Tic. A.Ş. & 909.015 .286 & - & $0,00 \%$ \\
\hline & 3- Armada Bilg. Sis. San. ve Tic. A.Ş. & 873.405 .805 & 4.751 .892 & $0,54 \%$ \\
\hline & 4- Datagate Bilg. Malz. Tic. A.Ş. & 228.648 .407 & - & $0,00 \%$ \\
\hline & 5- Despec Bilgisayar Paz. ve Tic. A.Ş. & 119.459 .538 & - & $0,00 \%$ \\
\hline & 6- Escort Teknoloji Yatırım A.Ş. & 76.556 .947 & - & $0,00 \%$ \\
\hline & 7- Fonet Bilgi Teknolojileri A.Ş. & 72.894 .627 & 1.993 .990 & $2,74 \%$ \\
\hline
\end{tabular}




\begin{tabular}{|c|c|c|c|c|}
\hline & 8- İndeks Bilg. Sist. San.Tic. A.Ş. & 1.519 .318 .763 & - & $0,00 \%$ \\
\hline & 9- Kafein Yazılım Hizm. Tic. A.Ş. & 110.478 .405 & 1.759 .325 & $1,59 \%$ \\
\hline & 10- Karel Elektronik San. ve Tic. A.Ş. & 775.387 .766 & - & $0,00 \%$ \\
\hline & 11- Kron Tel. Hizm. A.Ş. & 55.332 .585 & - & $0,00 \%$ \\
\hline & 12- Link Bilg. Sist. San. Tic. A.Ş. & 31.031 .480 & 595.475 & $1,92 \%$ \\
\hline & 13- Logo Yazılım San. ve Ticaret A.Ş. & 563.158 .201 & - & $0,00 \%$ \\
\hline & 14- Netaş Telekomünikasyon A.Ş. & 1.861.439.117 & 72.433 .757 & $3,89 \%$ \\
\hline & $\begin{array}{l}\text { 15- Plastikkart Akıllı Kart Sis. San. } \\
\text { Tic. A.Ş. }\end{array}$ & 78.656 .129 & 780.469 & $0,99 \%$ \\
\hline & 16- Smartiks Yazılım A.Ş. & 0 & - & $0,00 \%$ \\
\hline \multicolumn{2}{|c|}{ Toplam Teknoloji-Bilişim } & 7.926.430.008 & 82.314 .908 & $1,04 \%$ \\
\hline \multirow{6}{*}{$\begin{array}{l}\text { Eğitim, Sağlık, } \\
\text { Spor }\end{array}$} & 1- Beşiktaş Futbol Yat. San.Tic. A.Ş. & 952.861 .896 & - & $0,00 \%$ \\
\hline & 2- Fenerbahçe Futbol A.Ş. & 1.199.422.161 & - & $0,00 \%$ \\
\hline & 3- Galatasaray Sın. ve Tic Yat. A.Ş. & 990.135 .369 & - & $0,00 \%$ \\
\hline & 4- Lokman Hek. Eng. Sağ. Eği. A.Ş. & 286.698 .991 & - & $0,00 \%$ \\
\hline & 5- Mlp Sağlık Hizmetleri A.Ş. & 3.238 .877 .000 & 2.169.746.000 & $66,99 \%$ \\
\hline & 6- Trabzonspor Spor. Yat. Tic. A.Ş. & 400.868 .360 & - & $0,00 \%$ \\
\hline \multirow[t]{2}{*}{ Toplam Eğitim, } & Sağlık, Spor & 7.068.863.777 & 2.169.746.000 & $30,69 \%$ \\
\hline & 1- Deva Holding A.Ş. & 1.668 .440 .329 & 38.344 .852 & $2,30 \%$ \\
\hline \multirow{6}{*}{ İmalat } & 2- Borusan Man Boru San. Tic. A.Ş. & 6.824.019.354 & - & $0,00 \%$ \\
\hline & 3- Coca-Cola İçecek A.Ş. & 14.020.442.000 & 46.916 .000 & $0,33 \%$ \\
\hline & 4- Dyo Boya Fab. San. ve Tic. A.Ş. & 1.025.663.725 & - & $0,00 \%$ \\
\hline & 5- Ford Otomotiv Sanayi A.Ş. & 13.184.440.000 & 50.824 .000 & $0,39 \%$ \\
\hline & 6- Otokar Otomotiv ve Sav. San. A.Ş. & 2.302.746.000 & - & $0,00 \%$ \\
\hline & 7- Tüpraş-Türkiye Petrol Raf. A.Ş. & 40.035.727.000 & - & $0,00 \%$ \\
\hline \multicolumn{2}{|l|}{ Toplam İmalat } & 79.061.478.408 & 136.084 .852 & $0,17 \%$ \\
\hline \multicolumn{2}{|l|}{ Genel Toplam } & 393.764 .520 .296 & 24.244.541.562 & $6,16 \%$ \\
\hline
\end{tabular}

Tablo 2'de yer alan 72 şirketin, 2018 yılı itibariyle toplam varlıkları ve bilanço dışı bıraktıkları gelecekteki ödemeleri, KAP'ta yayımlanan denetim raporlarından temin edilerek Tablo 3 elde edilmiştir. Tablo 3'te şirketler bazında yer verilen bu bilgilerin BİST sektörler bazındaki durumu ise aşağıdaki Tablo 4'te özetlenmiştir. Bu sayede, IASB çalışmasında (Tablo 1) global çapta elde edilen sonuçların yerel düzeyde nasıl oluştuğunu karşılaştırma imkânı elde edilmiştir. 
Tablo 4: BİST Sektörleri Bazında Bilanço Dışı Ödemelerin Toplam Varlıklara Oranı

\begin{tabular}{|c|c|c|c|c|c|}
\hline \multirow{2}{*}{$\begin{array}{l}\text { Sektör } \\
\text { (BİST) }\end{array}$} & \multirow{2}{*}{$\begin{array}{l}\text { Toplam } \\
\text { Şirket } \\
\text { Sayısı }\end{array}$} & \multirow{2}{*}{$\begin{array}{l}\text { Toplam } \\
\text { (TL) }\end{array}$} & \multicolumn{2}{|c|}{$\begin{array}{l}\text { Bilanço } \\
\text { Bilanço Dişı BırakılanBırakılan } \\
\text { r Gelecekteki ÖdemelerGelecekteki }\end{array}$} & \multirow{2}{*}{$\begin{array}{r}\text { Diş1 } \\
\text { Toplam }\end{array}$} \\
\hline & & & (TL) & $\begin{array}{l}\text { Ödemeler/ } \\
\text { Varlıklar }\end{array}$ & \\
\hline Ulaştırma & 8 & 126.230.763.277 & 14.916.902.325 & $11,82 \%$ & \\
\hline Perakende & 11 & 31.248.417.194 & 5.385 .562 .594 & $17,23 \%$ & \\
\hline Seyahat & 1 & 93.948 .863 & - & $0,00 \%$ & \\
\hline Haberleşme & 2 & 78.963 .786 .000 & 1.508.740.000 & $1,91 \%$ & \\
\hline Elektrik Gaz ve Su & 8 & 58.287 .178 .789 & 41.424 .000 & $0,07 \%$ & \\
\hline $\begin{array}{l}\text { Kağıt ve Kağ } \\
\text { Ürünleri, Basım v } \\
\text { Yayın }\end{array}$ & $\begin{array}{l}\text { it } \\
e 13\end{array}$ & 4.883.653.980 & 3.766 .883 & $0,08 \%$ & \\
\hline Teknoloji-Bilişim & 16 & 7.926 .430 .008 & 82.314 .908 & $1,04 \%$ & \\
\hline Eğitim, Sağlık, Spor & 6 & 7.068.863.777 & 2.169.746.000 & $30,69 \%$ & \\
\hline İmalat & 7 & 79.061.478.408 & 136.084.852 & $0,17 \%$ & \\
\hline Toplam & 72 & 393.764 .520 .296 & 24.244.541.562 & $6,16 \%$ & \\
\hline
\end{tabular}

Tablo 1'de özetlenen IASB raporuna göre havayolu sektöründe bilanço dişı birakılan gelecekteki ödemelerin toplam varlıklara oranı \%28,8 iken taşımacılık sektöründe \%15,5 düzeyinde olduğu belirtilmişti. Tablo 4 'te ise BİST şirketlerine ilişkin özetlenen veriler değerlendirildiğinde; bu iki sektörün BİST'teki karşıllğ 1 olarak değerlendirilen ulaştırma sektöründe ise oran \%11,82 olarak gerçekleşmiştir. Bu yönüyle BİST ulaştırma sektöründeki faaliyet kiralaması düzeyinin dünya ortalamasının çok altında olduğu görülmektedir.

Yine IASB raporunda seyahat sektöründe oran \%28,6 iken BİST seyahat sektöründe bu oran hesaplanamayacak seviyededir. Bu yönüyle, BİST seyahat sektörü faaliyet kiralaması bakımından dünya genelindeki durumdan farklılaşmaktadır. Ancak bu durumun önemli bir nedeni olarak BIST seyahat sektöründe sadece 1 şirket olması olduğunu vurgulamak gerekmektedir. IASB raporuna göre; telekomünikasyon sektöründeki oran \%7,7 iken, bu sektörün BİST'teki karşılığ düzeyindedir. Oranlar dikkate alındığında BİST haberleşme sektöründeki faaliyet kiralaması düzeyinin dünya ortalamasının çok altında olduğu anlaşılmaktadır. Yine Enerji sektörü dikkate alındığında, IASB raporunda $\% 7,7^{\prime}$ lik bir oran ortaya çıkarken BIST'te yer alan elektrik, gaz ve su sektöründe bu oran $\% 0,07$ olarak hesaplanmıştır. IASB raporuna göre medya sektöründeki değeri \%7 iken, dağıtım sektöründe \%5,4 düzeyindedir. Bu iki sektörün BİST'teki karşılığı olarak değerlendirilen kağıt ve kağıt ürünleri, basım ve yayın sektöründe ise karşıllı̆ $1 \% 0,08$ olarak gerçekleşmiştir.

IASB raporunda bilgi teknolojileri sektöründeki değeri \%3,7 iken, bu sektörün BİST'teki karşılığı olduğu değerlendirilen teknoloji-bilişim sektöründe \%1,04 düzeyindedir. Sağlık 
sektöründe ise daha önce değinilen sektörlerin tersi bir etki görülmüş ve IASB raporunda oran \%3,8 iken BİST'te eğitim, sağlık, spor sektöründe bu oran \%30,69 olarak ölçülmüştür. BİST eğitim, sağlık, spor sektörüne bakıldığında toplam 6 şirket olduğu, bunlardan 4 tanesinin futbol kulübü 2 tanesinin ise hastane işletmesi olduğu görülmektedir. Futbol kulüplerinin etkisi dışarıda bırakılarak bu oran tekrar hesaplandığında oranın \%61,54 düzeyine çıktığı görülmektedir. Bu yönüyle BİST eğitim, sağlık, spor sektöründeki faaliyet kiralaması düzeyinin dünya ortalamasının çok üzerinde olduğu anlaşılmaktadır. Yine BİST sektörleri içinde en yüksek faaliyet kiralamasının da bu sektörde olduğu tespit edilmiştir.

IASB raporunda diğer sektörlerde ise değeri \%2,9 olarak belirtilmiştir. Bu çalışmada, diğer sektör olarak imalat sektörü seçilmiş ancak sektör içinde 179 tane şirket olduğu için içlerinden sadece 7 tanesi rastgele örneklem yöntemiyle seçilerek çalışmalara dahil edilmiştir. Dolayısıyla imalat sektöründen elde edilen sonuçlar farklı örneklem seçiminde değişebilecektir. Seçilen şirketler dikkate alınarak BİST imalat sektöründeki karşılığ hesaplandığında değerinin \%0,17 olduğu görülmüştür.

\section{Sonuç}

2006 yılından beri yürürlükte olan TMS 17 Kiralama İşlemleri Standardı, 2009 başından itibaren yürürlükten kaldırılmış olup yerine TFRS 16 Kiralamalar Standardı gelmiştir. Bu çalışmada söz konusu bu değişikliğin BİST'te işlem gören seçili bazı sektörlerdeki şirketlerin finansal oranları üzerindeki etkisi araştırma konusu edilmiştir.

TMS 17'ye göre, bir kiralama işlemi kiracı açısından finansal ve faaliyet kiralaması olarak ayrılmakta ve faaliyet kiralamasından kaynaklı işlemler bilanço dışında takip edilmektedir. TFRS 16'ya göre ise kiracı açısından bu ayrıma son verilmiş olup istisna olarak sayılan kiralama işlemleri (süresi 12 ay ve altı olanlar ile düşük değerli kiralamalar) dışında kalan tüm kiralama işlemleri finansal kiralama işlemi olarak kabul edilerek bu işlemden kaynaklı varlık ve yükümlülükler bilanço içine taşınmaktadır.

Standart değişikliğinde çok sayıda unsur etkili olmuştur. Buna göre faaliyet kiralaması olan şirketlerin bu işlemden kaynaklı varlık ve yükümlülüklerini bilanço dışında izlemesi şirketlerin gerçek yükümlülüklerinin analiz edilmesine engel oluşturmaktadır. Yine bu işlemlere ait amortismanlar ve finansman giderleri gelir tablosu dışında kalmaktadır. Sayılan bu durumlar faaliyet kiralaması olan şirketlerin gerçek durumundan farklı olarak değerlendirilmesine neden olmaktadır. TFRS 16'nın yürürlüğe girmesi ile birlikte şirketlerin daha şeffaf ve doğru finansal tablolar sunabilmesi hedeflenmiştir. Bu sayede ilgili kullanıcılar daha doğru performans ölçütlerine ulaşma imkânına kavuşacaktır.

Gerçekleştirilen IASB raporu ve BİST karşılaştırmasının sonuçları toplu şekilde değerlendirildiğinde BİST sektörleri genelinde karşılık olarak değeri ortalama \%6,16 olduğu görülmektedir. Dünya genelinde ise ortalama \%7,1 düzeyindedir. Bu yönüyle bakıldığında bu iki oranın birbirine yakın olduğu söylenebilecektir. Ancak, dünya genelinde faaliyet kiralaması işlemleri birden fazla sektör arasında daha dengeli bir dağılım gösterirken, BİST şirketleri bakımından durum daha farklıdır. BİST sektörleri bazında en yüksek faaliyet kiralaması oranı eğitim, sağlık ve spor sektöründe olup bu sektörün ortalaması, kalan diğer sektör ortalamalarının toplamına yakın bir düzeydedir. Diğer bir ifadeyle BİST şirketleri bağlamında faaliyet kiralaması işlemleri sağlı sektöründe aşırı bir yoğunlaşma göstermektedir. 
Öte yandan, oran şirketler bazında ele alındığında durumun farklılaştığı görülmektedir. Tablo 3'teki veriler dikkate alınarak şirketlerin oranları büyükten küçüğe sıralandığında ilk 3 sırada yer alan şirketlerin tamamının (Mavi Giyim, Teknosa ve Vakko) perakende sektöründe yer aldığı ve faaliyet kiralaması nedeniyle bilanço dışı bıraktıkları yükümlülüklerinin toplam varlıklarından daha yüksek olduğu görülmektedir. Örneğin oransal olarak ilk sırada yer alan Mavi Giyim'in 2018 yılındaki toplam varlıkları 1.343.910.000.-TL iken 2018 yılı itibariyle faaliyet kiralaması düzeyi 1.556.267.000.-TL'dir. Bu sonucun altında yatan ana unsurun perakende şirketlerinin özellikle mağaza kiralamalarını TMS 17 bağlamında faaliyet kiralaması olarak nitelendirmeleri olduğu değerlendirilmektedir.

Bilanço dışı bırakılan faaliyet kiralamasının toplam varlıklara oranı yerine miktar bakımından değerlendirilmesi durumunda ise ilk iki sırada havacılık şirketlerinin (THY ve Pegasus), üçüncü sırada ise sağlık şirketinin (MLP) geldiği görülmektedir. Havacılık şirketlerinin 2018 yılı itibariyle toplam faaliyet kiralaması yükümlülükleri 14.744.574.546.-TL olup bu rakam kalan şirketlerin toplam faaliyet kiralaması yükümlülüklerinden daha büyüktür. Bu bağlamda TMS 17' den TFRS 16'ya geçiş sonucunda Perakande, Havacılık ve Sağlık sektörlerinde yer alan şirketlerin daha yüksek etkiye maruz kalacağı değerlendirilmektedir.

\section{Kaynakça}

Akdoğan, H. N. (2019). UFRS 16 No'lu kiralama işlemleri standardının, UMS 17 No'lu finansal kiralama standardı ile karşılaştırılması, getirdiği yenilikler ve türkiye'deki halka açık perakende şirketlerinin finansal durumlarma etkisi üzerine örnek uygulama. (Yayınlanmamış Doktora Tezi). Ankara: Başkent Üniversitesi Sosyal Bilimler Enstitüsü.

Aktaş, R., Karğın, S., Arıcı, N. D. (2017). Yeni kiralamalar standardı UFRS 16'nın getirdiği yenilikler ve işletmelerin finansal tablolarına ve finansal oranlarına olası etkilerinin değerlendirilmesi. İşletme Araştırmaları Dergisi. 9(4): 858-881.

Beattie, V., Edwards, K., Goodacre, A. (1998). The impact of constructive operating lease capitalisation on key accounting ratios. Accounting and Business Research. 28(4):233-254

Beattie, V., Goodacre, A., Thomson:J. (2006). International lease-accounting reform and economic consequences: the views of U.K. users and preparers. The International Journal of Accounting. 41(2006): 75- 103.

Gritta, R., Lippman, E. (2010). Aircraft leasing and 1ts effect on air carriers debt burdens: A comparison over the past several decades. Journal of the Transportation Research Forum. 49(3): 101-110.

Hazır, Ç. A. (2019). TFRS 16-kiralamaların grup içi muhasebe politikaları çerçevesinde değerlendirilmesi. Muhasebe ve Finansman Dergisi, (82).

Hazir, Ç. A. (2018). Kiralama işlemlerinin TFRS 16'ya göre muhasebeleştirilmesi ve ölçülmesi. Mali Çözüm Dergisi, 28, 85-122.

IASB. (2016). IFRS 16 effects analysis. London: IFRS Foundation Publications Department.

Kaval, H. (2018). IFRS 16: kiralamalar standardının getirdikleri, ilk uygulama ve dönem sonu dönüştürme çalışmaları. Mali Çözüm Dergisi, 28, 11-43. 
Marşap, B., \& Yanık, S. (2018). IFRS 16 kapsamında kiralama işlemlerinin finansal raporlamaya etkisinin incelenmesi. Muhasebe ve Finansman Dergisi, (80).

MARŞAP, B., \& YANIK, S. (2018). Satış ve geri kiralama işlemlerinin IFRS 16 ve BOBI FRS çerçevesinde değerlendirilmesi. Ankara Hacı Bayram Veli Üniversitesi İktisadi ve İdari Bilimler Fakültesi Dergisi, 21(1), 1-15.

Öztürk, C. (2016). UFRS 16 kiralama işlemleri standardının eski UMS 17 standardı ile karşılaştırılması ve Almanya ve Türkiye'de hisse senetleri halka açık olan hava yolu şirketlerinin finansal durumuna etkisi. Muhasebe Bilim Dünyası Dergisi. 18(1): 1-50.

Parlak, N. (2018). Kiralama işlemlerinin UMS 17 ve UFRS 16 standartlarına göre karşılaştırılmalı olarak incelenmesi ve şirketlerin finansal durumuna etkisi. (Yayınlanmamış Doktora Tezi): Çorum: Hitit Üniversitesi Sosyal Bilimler Enstitüsü.

Sari, E. S., \& Güngör, N. UFRS 16'nın BİST 100 şirketlerinin finansal göstergelerine etkisi üzerine bir inceleme. PressAcademia Procedia, 9(1), 90-94.

Şenyiğit, Y. B. (2014). Finansal kiralama işlemlerinin muhasebeleştirilmesinde ve raporlanmasında beklenen değişiklikler: bir havayolu işletmesinde vak'a çalışması. Ç.Ü. Sosyal Bilimler Enstitüsü Dergisi. 23(1):288-299.

Tang, O., Fiedler, B. (2011). Lease accounting and US transportation industry. https://lms.polyu.edu.hk/media/13312/16_42.pdf

TFRS 16, https://www.kgk.gov.tr/Portalv2Uploads/files/Duyurular/v2/TFRS/TFRS_16.pdf

TMS

https://kgk.gov.tr/Portalv2Uploads/files/DynamicContentFiles/T\%C3\%BCrkiye\%20Muhas ebe\%20Standartlar\%C4\%B1/TMSTFRS2011Seti/TMS17.pdf 
EK 1: Seçilmiş Sektörlerdeki BİST Şirketlerinin Finansal/Faaliyet Kiralaması Durumları

\begin{tabular}{|c|c|c|c|c|}
\hline $\begin{array}{l}\text { SEKTÖR } \\
\text { (BİST) }\end{array}$ & ŞİRKET & $\begin{array}{l}\text { Finansal } \\
\text { Kiralama }\end{array}$ & $\begin{array}{l}\text { Faaliyet/ } \\
\text { Operasyonel* } \\
\text { Kiralama }\end{array}$ & Açıklama \\
\hline \multirow{8}{*}{ Ulaştırma } & 1- Beyaz Filo Oto Kiralama A.Ş. & YOK & YOK & $\begin{array}{l}\text { Şirket, Kiralayan } \\
\text { konumundadır. }\end{array}$ \\
\hline & 2- Çelebi Hava Servisi A.Ş. & VAR & VAR & \\
\hline & 3- Do \& Co Aktiengesellschaft & YOK & YOK & $\begin{array}{l}2017 \text { ve } 2018 \text { yılı } \\
\text { raporları yok }\end{array}$ \\
\hline & $\begin{array}{l}\text { 4- Gsd Denizcilik Gayr. İnş } \\
\text { San.Tic.A.Ş. }\end{array}$ & YOK & VAR & $\begin{array}{l}\text { Şirket, ayrıca } \\
\text { Kiralayan } \\
\text { konumundadır. }\end{array}$ \\
\hline & 5- Pegasus Hava Taşımacılığı A.Ş. & VAR & VAR & \\
\hline & 6- Reysaş Taşımacılık ve Loj Tic A.Ş. & VAR & VAR & \\
\hline & 7- Trabzon Liman İşletmeciliği A.Ş. & YOK & YOK & \\
\hline & 8- Türk Hava Yolları A.O. & VAR & VAR & \\
\hline \multirow{11}{*}{ Perakende } & 1- Adese Alışveriş Merk. Ticaret A.Ş. & VAR & YOK & \\
\hline & 2- Bim Birleşik Mağazalar A.Ş. & YOK & YOK & \\
\hline & 3- Bizim Toptan Satış Mağazaları A.Ş. & VAR & VAR & \\
\hline & 4- Carrefour Sabancı Tic. Mer. A.Ş. & VAR & VAR & \\
\hline & 5- Mavi Giyim Sanayi ve Ticaret A.Ş. & YOK & VAR & \\
\hline & 6- Metro Petrol ve Tes. San. Tic. A.Ş. & YOK & YOK & \\
\hline & 7- Migros Ticaret A.Ş. & YOK & YOK & \\
\hline & 8- Milpa Ticari ve Paz. San.Tic.A.Ş. & YOK & YOK & \\
\hline & 9- Şok Marketler Ticaret A.Ş. & VAR & VAR & \\
\hline & 10- Teknosa İç ve Diş Ticaret A.Ş. & VAR & VAR & \\
\hline & 11- Vakko Tek ve Haz. Giy. San. A.Ş. & YOK & VAR & \\
\hline Seyahat & \multicolumn{2}{|c|}{ 1- Flap Kongre Topl Hiz. Oto.Tur.A.Ş. YOK } & YOK & \\
\hline \multirow[t]{6}{*}{ Haberleşme } & 1- Turkcell İletişim Hizmetleri A.Ş. & VAR & YOK & $\begin{array}{l}\text { Şirket, TFRS 16'yı } \\
2018 \text { yılında erken } \\
\text { uygulama } \\
\text { kapsamında } \\
\text { uygulamıştır. }\end{array}$ \\
\hline & 2- Türk Telekomünikasyon A.Ş. & VAR & VAR & \\
\hline & 1- Akenerji Elektrik Üretim A.Ş. & VAR & YOK & \\
\hline & 2- Aksa Enerji Üretim A.Ş. & VAR & YOK & \\
\hline & 3- Aksu Enerji Ve Ticaret A.Ş. & VAR & YOK & \\
\hline & 4- Ayen Enerji A.Ş. & VAR & YOK & \\
\hline \multirow[t]{2}{*}{ Elektrik } & 5- Bomonti El. Müh. İnş.Tur.Tic.A.Ş. & YOK & YOK & \\
\hline & 6- Enerjisa Enerji A.Ş. & YOK & YOK & \\
\hline Gaz ve Su & 7- Odaş Elektrik Üretim San. Tic. A.Ş. & YOK & YOK & $\begin{array}{l}\text { Şirketin } 2 \text { tane } \\
\text { faaliyet kiralaması } \\
\text { işlemi vardır, ancak } \\
2018 \text { yılı itibariyle } \\
\text { bitmiştir. }\end{array}$ \\
\hline
\end{tabular}




\begin{tabular}{|c|c|c|c|}
\hline & 8- Zorlu Enerji Elektrik Üretim A.Ş. & YOK & $\begin{array}{l}\text { Şirketin faaliyet } \\
\text { kiralaması işlemleri } \\
2019 \text { yılı itibariyle } \\
\text { başlayacak olup, } 2018 \\
\text { yılında faaliyet } \\
\text { kiralaması işlemi } \\
\text { bulunmamaktadır. }\end{array}$ \\
\hline \multirow{6}{*}{ Kağıt ve } & 1- Alkım Kağıt Sanayi ve Ticaret A.Ş. YOK & YOK & \\
\hline & 2- Bak Ambalaj Sanayi ve Ticaret A.Ş. YOK & YOK & \\
\hline & 3- Doğan Burda Der. Yay. ve Paz. A.Ş. YOK & YOK & \\
\hline & 4- Doğan Basım ve Ambalaj San. A.Ş. VAR & VAR & \\
\hline & 5- Hürriyet Gazetecilik ve Matb. A.Ş. YOK & YOK & \\
\hline & 6- İhlas Gazetecilik A.Ş. & YOK & \\
\hline \multirow{2}{*}{$\begin{array}{l}\text { Kağıt } \\
\text { Ürünleri, }\end{array}$} & 7- Kaplamin Ambalaj San ve Tic. A.Ş. VAR & VAR & \\
\hline & 8- Kartonsan Karton San. ve Tic. A.Ş. YOK & YOK & \\
\hline Basım ve & 9- Tire Kutsan Kağıt ve Amb San. A.Ş. YOK & YOK & \\
\hline \multirow[t]{11}{*}{ Yayın } & $\begin{array}{l}\text { 10- Olmuksan International Paper YOK } \\
\text { Amb. San. Tic. A.S.. }\end{array}$ & YOK & \\
\hline & 11- Prizma Pres Mat. San. Tic. A.Ş. VAR & YOK & \\
\hline & 12- Saray Matb. Kağ. Kı. Tic. San. A.Ş. VAR & YOK & \\
\hline & 13- Viking Kağıt ve Selüloz A.Ş. & YOK & \\
\hline & 1- Alcatel Lucent Teletaş Tel. A.Ş. $\quad$ YOK & YOK & \\
\hline & 2- Arena Bilgisayar San. ve Tic A.Ş. YOK & YOK & \\
\hline & 3- Armada Bilg. Sist San ve Tic. A.Ş. VAR & VAR & \\
\hline & 4- Datagate Bilgisayar Malz. Tic. A.Ş. VAR & YOK & \\
\hline & 5- Despec Bilgisayar Paz. ve Tic. A.Ş. YOK & YOK & \\
\hline & 6- Escort Teknoloji Yatırım A.Ş. & YOK & \\
\hline & 7- Fonet Bilgi Teknolojileri A.Ş. & VAR & \\
\hline \multirow{2}{*}{ Teknoloji- } & 8- İndeks Bilg. Sist. Müh. San.Tic. A.Ş. VAR & YOK & \\
\hline & 9- Kafein Yazılım Hizmetleri Tic. A.Ş. VAR & VAR & \\
\hline \multirow[t]{7}{*}{ Bilişim } & 10- Karel Elektronik San.ve Tic. A.Ş. YOK & YOK & \\
\hline & 11- Kron Tel. Hizmetleri A.Ş. $\quad$ YOK & YOK & \\
\hline & 12- Link Bilg. Sis. Yaz. Don. Tic. A.Ş. YOK & VAR & \\
\hline & 13- Logo Yazılım San. ve Ticaret A.Ş. VAR & YOK & \\
\hline & 14- Netaş Telekomünikasyon A.Ş. $\quad$ YOK & VAR & \\
\hline & $\begin{array}{l}\text { 15- Plastikkart Akıllı Kart İl. Sis. San. VAR } \\
\text { Tic. A.Ş. }\end{array}$ & VAR & \\
\hline & 16- Smartiks Yazilim A.Ş. & YOK & $\begin{array}{l}2017 \text { ve } 2018 \text { y1lı } \\
\text { raporları yok }\end{array}$ \\
\hline Eğitim, & 1- Beşiktaş Futbol Yat. San.Tic. A.Ş. & YOK & $\begin{array}{l}\text { Şirketin özel hesap } \\
\text { dönemi vardır. Bu } \\
\text { nedenle } 2017 \text { yılı } \\
\text { raporu dikkate } \\
\text { alınmıştır. }\end{array}$ \\
\hline
\end{tabular}




\begin{tabular}{|c|c|c|c|c|}
\hline \multirow[t]{8}{*}{ Spor } & 2- Fenerbahçe Futbol A.Ş. & YOK & YOK & $\begin{array}{l}\text { Şirketin özel hesap } \\
\text { dönemi vardır. Bu } \\
\text { nedenle } 2017 \text { yılı } \\
\text { raporu dikkate } \\
\text { alınmıştır. }\end{array}$ \\
\hline & $\begin{array}{l}\text { 3- Galatasaray Sportif Sınai ve Ticar } \\
\text { Yat. A.Ş. }\end{array}$ & YOK & YOK & $\begin{array}{l}\text { Şirketin özel hesap } \\
\text { dönemi vardır. Bu } \\
\text { nedenle } 2017 \text { yılı } \\
\text { raporu dikkate } \\
\text { alınmıştır. }\end{array}$ \\
\hline & $\begin{array}{l}\text { 4- Lokman Hekim Engürüsağ Sağ } \\
\text { Tur. Eği. A.Ş. }\end{array}$ & VAR & YOK & \multirow{10}{*}{$\begin{array}{l}\text { Şirketin özel hesap } \\
\text { dönemi vardır. Bu } \\
\text { nedenle } 2017 \text { yılı } \\
\text { raporu dikkate } \\
\text { alınmıştır. }\end{array}$} \\
\hline & 5- Mlp Sağlık Hizmetleri A.Ş. & VAR & VAR & \\
\hline & $\begin{array}{l}\text { 6- Trabzonspor Sportif Yat. Fut. İşl } \\
\text { Tic. A.Ş. }\end{array}$ & YOK & YOK & \\
\hline & 1- Deva Holding A.Ş. & YOK & VAR & \\
\hline & 2- Borusan Man. Boru San.ve Tic. A.Ş & VAR & YOK & \\
\hline & 3- Coca-Cola İçecek A.Ş. & VAR & VAR & \\
\hline \multirow[t]{4}{*}{ İmalat } & 4- Dyo Boya Fab. San. ve Ticaret A.Ş. & YOK & YOK & \\
\hline & 5- Ford Otomotiv Sanayi A.Ş. & YOK & VAR & \\
\hline & 6- Otokar Oto. ve Sav. Sanayi A.Ş. & YOK & YOK & \\
\hline & 7- Tüpraş-Türkiye Petrol Raf. A.Ş. & YOK & YOK & \\
\hline
\end{tabular}

